\title{
FRESH-WATER GREEN ALGAE (CHLOROPHYTA) AS A NATURAL PIGMENT FOR MOJOSARI DUCKS
}

\author{
B.Indarsih, Asnawi and D.K. Purnamasari \\ Faculty of Animal Science, Mataram University, \\ Jalan Majapahit No 62 Mataram Lombok, NTB, 83125 - Indonesia \\ CorrespondingE-mail:budiindarsih@gmail.com
}

Received January 17, 2015; Accepted February 14, 2015

\begin{abstract}
ABSTRAK
Penelitian dilakukan dengan rancangan acak lengkap untuk mengetahui penggunaan ganggang hijau air tawar segar sebagai pewarna alami kuning telur itik Mojosari selama periode bertelur terhadap performan produksi dan kualitas telur. Sebanyak 80 ekor itik petelur umur 36 minggu dibagi menjadi empat perlakuan dan empat ulangan terdiri dari 5 ekor. Pakan diformula menggunakan konsentrat komersial, dedak, dan jagung kuning (2:4:4) sesuai dengan standar pakan komersial sebagai kontrol, dan tiga perlakuan lain dengan menambahkan 2, 4, dan 8\% ganggang hijau. Konsumsi pakan, produksi telur dan konversi pakan dipengaruhi oleh pemberian ganggang hijau $(\mathrm{p}<0.05)$. Produksi telur dan konversi pakan menunjukkan perbaikan pada level 2 dan 4\%. Indek kuning telur, indeks albumen, Haugh Unit dan ketebalan kulit telur tidak dipengaruhi oleh pemberian ganggang hijau $(\mathrm{P}>0.05)$ kecuali warna kuning telur. Warna kuning telur mengalami perubahan lebih baik dalam waktu 7 hari setelah pemberian pakan yang mengandung ganggang hijau. Ganggang hijau dapat digunakan sebagai pewarna alami kuning telur dan pada level $8 \%$ dalam ransum meningkatkan pigmentasi kuning telur itik hingga mencapai skor tertinggi diukur Roche Yellow Color pada skala 15.
\end{abstract}

Kata kunci: ganggang hijau, jagung, dedak, warna kuning telur, produksi telur.

\begin{abstract}
An experiment in a completely randomize design was undertaken to study the use of fresh-water green algae as a yolk coloring agent in Mojosari ducks during a laying period on productive performance and egg quality from 36 to 44 wk of age. A total of 80 thirty-six wk-old laying ducks were divided into four dietary treatments and each of four replicates with 5 birds. Diets were formulated with a commercial concentrate, rice bran and yellow corn (2:4:4) according to a commercial standard diet as a control, and three other dietary treatments with 2,4 or $8 \%$ of green algae were included. Fresh water green algae had a significant effect on the feed uptake, egg production, and feed conversion ratio (FCR) $(p<0.05)$. Egg production and FCR improved at added 2 and $4 \%$ green algae. No differences were observed in egg yolk index, albumen index, Haugh Unit, and egg shell thickness $(\mathrm{P}>0.05)$ except egg yolk color. The yolk color increased within 7 days after feeding with the test diets. The present study indicated that fresh-water green algae could be used as a natural coloring agent in laying ducks and at $8 \%$ of green algae showed the highest score of (Roche Yellow Color-15).
\end{abstract}

Keywords: green algae, corn, rice bran, egg production, yolk color

\section{INTRODUCTION}

The production of Ducks (Anas platyrhychos) as a food source in Indonesia have become of high importance in the last few years. Duck farming is regarded as the most reliable business in rural areas because it has a very large contribution to the small farmers in rural areas 
both to increase their income and to support animal protein demand.

Mojosari ducks are one of the Indonesian superior laying ducks from areas of Mojokerto, East Java. In addition to producing high eggs, the duck meat is delicious and the demand of duck products tends to increase recently. Because ducks are more resistant to diseases and can easily managed by small farmers, they become more popular and are of higher benefit compared with chicken. The value of selling duck eggs remains higher than chicken eggs because of the larger size of duck eggs and the price of individual eggs, not at the mass weight base. Duck eggs are also used as raw materials for salted eggs in food industries, which cannot be substituted by eggs from other layer birds of any types of poultry furthermore, egg yolk color is an important criterion for consumers.

Yellow corn is the main ingredient used in most poultry diets to supply xanthophylls for the yolk color, approximately 40 to $60 \%$ (Leeson and Caston, 2004) 30 to 50\% (Cho et al., 2013), 65\% (Moeini et al., 2013). However, xanthophylls for yolk color only relied on corn were not able to satisfy the consumer's preferences due to the fact that total carotenoid of corn was only $22 \mathrm{mg} / \mathrm{kg}$ (Kijparkorn et al., 2010), which was lower than forage materials (Hammershøj et al., 2010). Therefore the use of several natural materials to improve yolk color have been implemented in layers such as marigold and skin orange (Hasin et al., 2006), marigold flower (MF), safflower petals (SP), red pepper meal (RPM) (Rowghani et al., 2006), sano flower (Kijparkorn et al., 2010), paprika (Lokaewmanee et al., 2011), turmeric root (TR) and annatto seed (AS) (Laganá et al., 2011) and duckweed in laying ducks (Indarsih and Tamsil, 2012). Indonesian small farmer cannot afford it because of limited commercial and natural availability as well as relatively expensive.

A natural source of xanthophylls, such as green algae from which its lutein is important for pigmentation in fish and poultry (Jin et al., 2003) is a potential coloring agent. Green algaes are different from the other plant divisions because they have a clear green color and contain the pigment chlorophyll: a, b and c, carotene and xanthophylls (Lewis and McCourt, 2004). Green algae (unidentified chlorophyta) growing in fresh water is probably one of alga groups which belongs to macroalgaes and the largest group of algae (Chojnacka et al., 2012) and a well-known water grass by duck growers. Feeding with $5 \%$ macroalgae (Ulva lactuca) improved fish growth and as a protein source replacing common fish meal (Wassef, 2005). This potential macroalgae would be beneficial to reduce feed cost and improved performance when successfully applied. However, to the best of our knowledge, no previous studies have investigated the use of fresh water green algae (chlorophyta)for ducks. Therefore this study was conducted to evaluate fresh water green algae as a source of a natural pigment.

\section{MATERIALS AND METHODS}

\section{Animals and management}

A total of 80 thirty-six wk-old were obtained from the local breeder, then wing banded and weighed individually and reared in groupedhoused in an intensive barn from bamboo with average density of 4 birds $/ \mathrm{m}_{2}$ and zinc roof in an open-sided house with uncontrolled temperature. Floors were constructed from solid soil with rice hulls as the litter. The cages were equipped with two rounded plastic feeder with $20 \mathrm{~cm}$ in diameters for a feeder trough and for drinking water. Routine management practices such as health and disease control programs were applied with the ground for combating the recent disease outbreak on new castle diseases in Indonesia.

\section{Diets and Treatments}

The birds were assigned to a completely randomized design. Eighty laying ducks were divided into 4 groups of dietary treatments with four replicates (20 birds/dietary treatment) and fed on a commercial layer concentrate containing 38 percent crude protein and mixed with yellow corn and rice bran in ratio of 2:4:4 respectively according to a commercial standard feed acting as the control group. This formula was commonly used and applied by the local growers. The three other dietary treatments were included 2, 4 and $8 \%$ of dry matter. Therefore the ratio of the basal diets was in a range to contain from 2,600 to $2,800 \mathrm{kcal}$ of $\mathrm{ME} / \mathrm{kg}$ until 8 weeks of the experimental period. Feeding method was restricted to $190 \mathrm{~g} / \mathrm{bird} /$ day and provided twice a day (6.00 and 17.00) to avoid the over spilling feed. Birds had free access to drinking water during the experimental period. The diets were offered in a slurry form. Spillage of the feed was calculated by weighing and drying the remaining feed on the feeder. The fresh water green algaes (unidentified chlorophyta) were harvested from 
the local rivers near the duck farm, then washed and chopped into small size before feeding.

Prior to the study, all feed ingredients were investigated for the proximate composition (Table 1) according to the methods of the Association of Official Analytical Chemists (AOAC, 1995) and performed in the analytic laboratory of Mataram University.

\section{Measurements}

The data on feed consumption, egg production and egg weight were recorded daily from 36 to 44 weeks (for the 8- wk of the experimental period). Egg quality characteristics viz. albumen index, egg yolk index, Haugh unit, shell thickness and yolk pigmentation were measured on wk 1 to 6 of the experimental production period. A total number of 192 eggs ( 8 eggs from each dietary treatment) per collection were taken and broken out on a clean Petri dish and then yolk color was measured against the Roche Yolk Color Fan scale (RYCF) as a tool for a standard color. This work was carried out at the Laboratory of Animal Product Processing Technology- Faculty of Animal Science, Mataram University.

\section{Data Analysis}

The data collected for 8 wk of the experimental study were analyzed as a completely randomized design and subjected to the General Linear Model (GLM) procedure of SAS version 8 (SAS, 1999). To compare means, Duncan's multiple range test was applied at the level of less than $5 \%$.

\section{RESULTS AND DISCUSSION}

\section{Production Performance}

The effects of the green algae inclusion in three different levels are presented in Table 2 and Tabel 3. There were significant differences observed all dietary treatments including the control diet groups for egg production, egg weight feed $/ \mathrm{kg}$ eggs, and feed intake. Feeding green algae from 2 to $4 \%$ into the layer diets did not have any negative effect on egg production. However, by adding $8 \%$ a change in performance was observed which reduced egg production to $46.7 \%$. This is inconsistent with previous studies (Rowghani et al., 2006; Esfahani-Mashhour et al., 2009; Kijparkorn et al., 2010; Lokaewmanee et al., 2011), who found no significant production performance due to additives. Our study indicates that green algae fed at lower levels (T-1 and T-2) improves feed conversion ratio (FCR), explaining the nutrient content of green algae particularly protein have contributed to the egg production. The T-3 groups, however, because of the lowest dietary energy and the highest dietary crude fibers increased the feed consumption at the expense of the lower production performance. In the work of Abudabos et al. (2013) where broilers were fed 0, 10 and $30 \mathrm{~g} / \mathrm{kg}$ green seaweed (Ulva lactuna), the best results were noted in the groups with addition of $30 \mathrm{~g} / \mathrm{kg}$ of green seaweed. Dressing percentage and breast meat yield performed higher in the birds fed $30 \mathrm{~g} / \mathrm{kg}$ of green seaweed than those fed $10 \mathrm{~g} / \mathrm{kg}$. Similar trends were also observed for serum lipid, cholesterol and uric acid concentration. The reasons were claimed due to higher contents of limiting amino acids

Table 1: Chemical Composition of the Dietary Ingredients (\%)

\begin{tabular}{lcccc}
\hline \multirow{2}{*}{ Chemical Composition } & \multicolumn{4}{c}{ Ingredients } \\
\cline { 2 - 5 } & $\begin{array}{c}\text { Commercial Protein } \\
\text { Concentrate (CC) }\end{array}$ & $\begin{array}{c}\text { Green Algae } \\
\text { (GA) }\end{array}$ & $\begin{array}{c}\text { Yellow Corn } \\
\text { (YC) }\end{array}$ & $\begin{array}{c}\text { Rice Bran } \\
\text { (RB) }\end{array}$ \\
\hline Moisture & 11.00 & 89.25 & 11.75 & 9.46 \\
Crude protein (CP) & 38.01 & 21.74 & 8.53 & 6.80 \\
Crude fibre (CF) & 5.00 & 27.40 & 2.64 & 20.00 \\
Ether extract & 2.60 & 2.98 & 2.83 & 3.06 \\
Ash & 2.78 & 22.19 & 1.94 & 18.20 \\
NFE* & 40.62 & 25.69 & 84.06 & 51.94 \\
\hline
\end{tabular}

*Nitrogen-Free Extract $($ calculated by difference $)=100-($ protein + lipid + ash + fiber $)$ 
Table 2. Ingredient and Calculated Nutrient Contents of the Experimental Diets

\begin{tabular}{|c|c|c|c|c|}
\hline \multirow{2}{*}{ Ingredient (\%) } & \multicolumn{4}{|c|}{ Dietary Treatment } \\
\hline & $\mathrm{T}-0$ & $\mathrm{~T}-1$ & $\mathrm{~T}-2$ & $\mathrm{~T}-3$ \\
\hline Rice bran & 40 & 40 & 40 & 40 \\
\hline Yellow corn & 40 & 38 & 38 & 38 \\
\hline Commercial concentrates & 20 & 20 & 18 & 14 \\
\hline Green algae & 0 & 2 & 4 & 8 \\
\hline \multicolumn{5}{|l|}{ Calculated analysis } \\
\hline Metabolizable energy (ME) (kcal/kg) & 2,780 & 2,734 & 2,687 & 2,600 \\
\hline Crude protein $(\%)$ & 13.77 & 14.07 & 13.22 & 13.09 \\
\hline Crude fibre $(\%)$ & 10.06 & 10.20 & 10.65 & 11.55 \\
\hline Calcium (\%) & 2.70 & 2.82 & 3.27 & 2.40 \\
\hline Available phosphorus (\%) & 1.02 & 1.10 & 1.19 & 1.36 \\
\hline
\end{tabular}

Table 3. Effect of Different Levels of Green Algae on Production Performance of the Laying Ducks During The 8 -Wk Experimental Period (From Wk 36 to 44)

\begin{tabular}{lrrrrr}
\hline \multirow{2}{*}{ Performance } & \multicolumn{5}{c}{ Dietary Treatment } \\
\cline { 2 - 6 } & \multicolumn{1}{c}{$\mathrm{T}-0$} & \multicolumn{1}{c}{$\mathrm{T}-1$} & \multicolumn{1}{c}{$\mathrm{T}-2$} & \multicolumn{1}{c}{$\mathrm{T}-3$} & SEM \\
\hline Feed intake (g/bird) & $154.0^{\mathrm{b}}$ & $161.6^{\mathrm{ab}}$ & $168.7^{\mathrm{a}}$ & $171.9^{\mathrm{a}}$ & 2.4 \\
Egg production (\%) & $53.9^{\mathrm{b}}$ & $68.2^{\mathrm{a}}$ & $71.7^{\mathrm{a}}$ & $46.7^{\mathrm{b}}$ & 4.2 \\
FCR (kg feed/kg eggs) & $4.72^{\mathrm{b}}$ & $3.88^{\mathrm{b}}$ & $3.74^{\mathrm{b}}$ & $5.76^{\mathrm{a}}$ & 0.38 \\
Mortality (\%) & 0 & 0 & 0 & 0 & \\
\hline
\end{tabular}

a-b Means within a row with no common superscript differ significantly $(\mathrm{p}<0.05)$. Ducks fed RB 40\%, YC $40 \%$, CC $20 \%$ with no GA (T-0); ducks fed RB 40\%, YC 38\%, CC 20\%, GA 2\% (T-1); ducks fed RB 40\%, YC 38\%, CC 18\%, GA 4\% (T-2); ducks fed RB 40\%, YC 38\%, CC 14\%, GA 8\% (T-3)

SEM: standard error of mean.

(methionine and threonine) of green seaweed. A study of Indarsih and Tamsil (2012) showed the much lower productive performance of laying ducks fed with $20 \%$ duckweed than this present study may explain the potential green algae as an additive or a feedstuff for ducks can be fed up 4\% for the maximum egg production.

\section{Egg quality}

The dietary treatments had no significant effect on egg yolk index, egg weight, Haugh unit and egg shell thickness (Table 4). This is consistent with earlier studies (Kijparkorn et al., 2010; Abiodun et al., 2014). However, the yolk color was significantly changed $(p<0.05)$ according to the added levels of green algae into the diet. The differences in yolk color between the experimental diets showed that an increase in pigmentation of egg yolk color was also dependent on the differences feed intake from 
which algae intake was also different. This is similar to previous studies (Rowghani et al., 2006; Laganá et al., 2011; Abiodun et al., 2014). In the present study, improvement in yolk colors was observed 7 days after feedingthe test diets, and yolk color hanged rapidly in a response to feeding green algae, showing the average values were higher than the control depending on the treatments, then it remained constant until observation of day 42. The highest level showed the best pigmentation (15.0) (Table 5). A study of Rowghani et al. (2006) showed that the yolk color improvement by adding marigold flower, safflower petals, and red pepper meal was longer than this present study. These authors claimed that increased yolk color by feeding basal diets (wheat and yellow corn based diet) with those additive sources can be observed 10-13 days after feeding. The work of Laganá et al. (2011) showed the linier improvement in yolk color for birds fed $2 \%$ annato seed from day 0 to 28 with maximum score was 11.8. It means that green algae used in our study contained high xanthophylls and were fast deposited into yolk although the content of xanthophylls of green algae was not analyzed. It is interesting to note that $4 \%(40 \mathrm{~g} / \mathrm{kg})$ green algae in the present study produced RYC values higher than $4 \%$ using marigold or skin orange (13.33 versus 8.2 or 3.3) as observed by Hasin et al. (2006) which marigold and skin orange contained $156.32 \mathrm{mg} / \mathrm{kg}$ and $83.02 \mathrm{mg} / \mathrm{kg} \mathrm{DM}$ xanthophylls respectively. In other studies, egg

Table 4. Egg Quality From Laying Ducks Fed a Diet Containing Different Levels of Green Algae During the 8- Wk Experimental Period (From Wk 36 to 44)

\begin{tabular}{lccccc}
\hline \multirow{2}{*}{\multicolumn{1}{c}{ Variable }} & \multicolumn{5}{c}{ Dietary Treatment } \\
\cline { 2 - 6 } & T-0 & T-1 & T-2 & T-3 & SEM \\
\hline Egg yolk index & 0.466 & 0.443 & 0.432 & 0.374 & 0.005 \\
Albumen index & 0.127 & 0.130 & 0.136 & 0.135 & 0.007 \\
Egg weight (g) & 62.97 & 65.71 & 66.22 & 67.59 & 1.29 \\
Haugh unit & 90.87 & 94.94 & 86.03 & 99.03 & 6.14 \\
Egg shell thickness (mm) & 0.47 & 0.45 & 0.46 & 0.43 & 0.01 \\
Egg yolk color (RYC) & $9.95^{\mathrm{c}}$ & $3.90^{\mathrm{b}}$ & $14.28^{\mathrm{b}}$ & $15.00^{\mathrm{a}}$ & 0.17 \\
\hline
\end{tabular}

a-c Means within columns with no common superscript differ significantly $(\mathrm{p}<0.05)$. Ducks fed RB $40 \%$, YC $40 \%$, CC 20\% (T-0); ducks fed RB 40\%, YC 38\%, CC 20\%, GA 2\% (T-1); ducks fed RB 40\%, YC 38\%, CC $18 \%$, GA 4\% (T-2); ducks fed RB 40\%, YC 38\%, CC 14\%, GA $8 \%$ (T-3).

SEM: standard error of mean

Table 5. Yolk Color of Duck Eggs Fed Diets Containing Different Inclusion Levels of Green Algae During the 8- Wk Experimental Period (From Wk 36 to 44)

\begin{tabular}{|c|c|c|c|c|c|c|}
\hline \multirow{2}{*}{ Treatment } & \multicolumn{6}{|c|}{ Yolk Color Values on Different Observation Days } \\
\hline & 7 & 14 & 21 & 28 & 35 & 42 \\
\hline $\mathrm{T}-0$ & 9.01 & 9.73 & 10.71 & 9.73 & 9.31 & 10.71 \\
\hline $\mathrm{T}-1$ & 13.73 & 13.71 & 14.00 & 13.70 & 14.00 & 14.22 \\
\hline $\mathrm{T}-2$ & 14.03 & 14.32 & 14.31 & 14.31 & 14.32 & 14.34 \\
\hline $\mathrm{T}-3$ & 15.00 & 15.00 & 15.00 & 15.00 & 15.00 & 15.00 \\
\hline
\end{tabular}

Ducks fed RB 40\%, YC 40\%, CC 20\% with no GA (T-0); ducks fed RB 40\%, YC 38\%, CC 20\%, GA $2 \%$ (T1); ducks fed RB 40\%, YC 38\%, CC 18\%, GA 4\% (T-2); ducks fed RB 40\%, YC 38\%, CC 14\%, GA 8\% (T3) 
yolk color reached to $13.70 \pm 1.4 \mathrm{RYC}$ with $20 \%$ added duckweed (Indarsih and Tamsil, 2012). In a study where layers were fed with $2 \%$ annato seed, pigmentation showed intensively after 28 days, reached to 11.8 (Laganá et al., 2011). The highest yolk color index (5.5) was observed by feeding $1 \%$ of costmary (Nobakhtand Moghaddam, 2013). Feeding with $2 \%$ red algae in laying hens, yolk color was lower $(12.51 \pm 0.87)$ than the control diet (13.21 \pm 0.69$)$ as the company's formula (Ozaki et al., 2013). Observed by Moeini et al. (2013), incorporating of $3 \%$ red pepper in $65 \%$ corn diet, resulted in 13.3 RYC. This clearly suggests that green algae can be used as a natural potential coloring agent for producing desirable egg-yolk color at low levels. A possible explanation for this is again that the level of b-carotene and xanthophylls in fresh green algae was quite high. Therefore further studies are needed to clarify more details concerning the xanthophylls content and to identify the species of this chlorophyta.

\section{CONCLUSIONS}

The results of the present study indicated that fresh-water green algae could be used as a natural coloring agent in laying ducks. To the best yolk color values (15.0) was observed in a diet containing $8 \%$ of green algae added into a conventional ration for laying ducks without any negative effect on productive performance.

\section{ACKNOWLEDGEMENT}

We wish to thank to the Directorate General of Higher Education for financial support through the Competitive Fund of MP3EI (Master plan for the Acceleration and Growth of Indonesian Economic Development 2012-2025) under the Contract Agreement No: 273/SP2H/PL/ DIT.LITABMAS/VII/2013, 15 July 2013.

\section{REFERENCES}

Abiodun, B. S., A.S. Adedeji and E. Abiodun. 2014. Lesser known indegrnous vegetables as potential natural egg colourant in laying chickens. J. Anim. Technol. 56:18

Abudabos, A. M., A. B. Okab, R.S. Aljumaah, E.M. Samara, K. A. Abdoun and A.A. AlHaidary. 2013. Nutritional value of green seaweed (Ulva latuca) for broiler chickens. Italian. J. Anim. Sci. 2:177-181

AOAC (Association of Official Analytical
Chemists). 1995. International Official Methods of Analysis. 16 $6^{\text {th }}$ edn. Arlington, Virginia, USA.

Cho, J.H., Z.F. Zhang and I.H. Kim. 2013. Effects of canthaxanthin on egg production, egg quality, and egg yolk color in laying hens. J. Agric. Sci. 5: 269-275.

Chojnacka, K., A. Saeid and I. Michalak. 2012. The possibilities of the application of algal biomass in the agriculture. Chemik. 66: 1235-1248.

Esfahani-Mashhour, M., H. Moravej, H. Mehrabani-Yeganeh and S. H. Razavi. 2009. Evaluation of coloring potential of dietzia natronolimnaea biomass as source of canthaxanthin for yolk color pigmentation. Asian- Aust. J. Anim. Sci. 22: 254-259

Hammershøj, M., U. Kidmose and S. Steenfeldt. 2010. Deposition of carotenoids in egg yolk by short-term supplement of coloured carrot (Daucus carota) varieties as forage material for egg-laying hens. J. Sci. Food Agric. 90: 1163-1171

Hasin, B.M., A.J.M. Ferdaus, M.A. Islam, M.J. Uddin and M.S. Islam. 2006. Marigold and orange skin as egg yolk color promoting agents. Inter. J. Poult. Sci. 5: 979-987.

Indarsih, B. and M. H. Tamsil. 2012. Feeding diets containing different forms of duckweed on productive performance and egg quality of ducks. Media Peternakan. 35: 128-132

Leeson, S. and L. Caston. 2004. Enrichment of eggs with lutein. Poult. Sci. 83:1709-1712

Jin, E.S., J.W.E. Polle, H.K. Lee, S.M. Hyun and M. Chang. 2003. Xanthophylls in microalgae: from biosynthesis to biotechnological mass production and application. J. Microbiol. Biotechnol. 13: 165-174.

Kijparkorn, S., H. Plaimast and S. Wangsoonoen. 2010. Sano (Sesbania javanica Miq.) flower as a pigment source in egg yolk of laying hens. Thai J. Vet. Med. 40: 281-287.

Laganá, C., C.C. Pizzolante, E.S.P.B. Saldanha and J.E. Moraes. 2011. Turmeric root and annato seed in second-cycle layer diets: performance and egg quality. Braz. J. Poult. Sci. 13: 171-176.

Lewis, L.A. and R. M. McCourt. 2004. Green algae and the origin of land plants. Am. J. Bot. 91: 1535-1556.

Lokaewmanee, K., K. Yamauchi, T. Komori and K. Saito. 2011. Enhancement of egg yolk 
color by paprika combined with a probiotic. J. Appl. Poult. Res. 20: 90-94.

Moeini, M.M., S.H. Ghazi, S. Sadeghi and M. Malekizadeh. 2013. The effect of red pepper (Capsicum annuum) and marigold flower (Tageteserectus) powder on egg production, egg yolk color and some blood metabolites of laying hens. Iranian J. Appl. Anim. Sci. 3: 301-305.

Nobakht, A. and M. Moghaddam. 2013. The effects of different levels of costmary (Tanacetum balsamita) medicinal plant on performance, egg traits and blood biochemical parameters of laying hens. Iranian J. Appl. Anim. Sci. 3:307-312.

Ozaki, H., M. Kawahara, R. Nogami, Y. Yamada and H. Takahashi. 2013. Supplemental red alga, Gracilaria vermiculophylla, from a Brackish Japanese lake, strengthens egg shells and improves the Haugh unit of eggs in laying hens. J. Fisheries Livest. Prod.
2:110.

Rowghani, E., A. Maddahian and M. Arab Abousadi. 2006. Effects of addition of marigold flower, safflower petals, red pepper on egg-yolk color and egg production in laying hens. Pak. J. Biol. Sci. 9: 1333-1337.

SAS Institute. 1999. SAS ${ }^{\circledR}$ User's Guide: Statistics, Version 8. SAS Institute Inc., Cary, NC., USA.

Suresh, B.N., B.S.V. Reddy, B.H. Manjunatha Prabhu and N. Suma. 2009. Egg Quality Traits of Layers fed sugarcane press residue with biotechnological agents. Inter. J. Poult. Sci. 8: 677-683

Wassef, E.A. 2005. Alternative protein sources for fish feeds in Egypt,. In : Montero D., B. Basurco, I., Nengas, M. Alexis and M. Izquierdo (eds.). Mediterranean fish nutrition. Zaragoza : Ciheam, pp 127-141 